\title{
Cytotaxonomy and karyoevolution of the genus Crenicichla (Perciformes, Cichlidae)
}

\author{
Denise Corrêa Benzaquem ${ }^{1}$, Eliana Feldberg ${ }^{1}$, Jorge Ivan Rebelo Porto ${ }^{1}$, Maria Claudia Gross ${ }^{1}$ \\ and Jansen Alfredo Sampaio Zuanon ${ }^{2}$ \\ ${ }^{1}$ Laboratório de Genética de Peixes, Instituto Nacional de Pesquisas da Amazônia, \\ Coordenação de Pesquisas em Biologia Aquática, Manaus, AM, Brazil. \\ ${ }^{2}$ Laboratório de Sistemática e Ecologia de Peixes, Instituto Nacional de Pesquisas da Amazônia, \\ Coordenação de Pesquisas em Biologia Aquática, Manaus, AM, Brazil.
}

\begin{abstract}
Karyotypes of six cichlid species of the genus Crenicichla were investigated. The species C. cincta, C. inpa, C. reticulata, $C$. lugubris, and $C$. cf. johanna were collected from Amazon basin, and $C$. britskii was collected from the Paraná-Paraguai basin. All of the analysed species showed $2 \mathrm{n}=48$ chromosomes; however, C. cincta, C. lugubris, $C$. cf. johanna, and $C$. britskii had a karyotype formula of $8 \mathrm{M}-\mathrm{SM}+40 \mathrm{ST}-\mathrm{A}, \mathrm{FN}=56$, while $C$. inpa and $C$. reticulata exhibited the formula $6 \mathrm{M}-\mathrm{SM}+42 \mathrm{ST}-\mathrm{A}, \mathrm{FN}=54$. Analysis of active Ag-NORs revealed two NOR-bearing chromosomes in all species; however, theses cistrons were located on different chromosome pairs and/or in different chromosome locations in each species. This condition bears evolutionary significance, since it is the main chromosome marker of the process of karyotypic evolution among the species of the genus Crenicichla. In general, C-banding revealed a similar constitutive heterochromatin pattern in all species, although it was possible to detect some features that led us to infer that Crenicichla also presents a species-specific heterochromatin pattern.
\end{abstract}

Key words: karyotype, pike cichlid, chromosome marker, Amazon.

Received: August 23, 2006; Accepted: June 8, 2007.

In the Perciformes group, cichlids are the most species-rich non-Ostariophysan freshwater fish family in the world, and one of the largest vertebrate families, with at least 1,300 species and estimates to approach 1,900 species (Kullander, 1998). The pike cichlids of the genus Crenicichla Heckel, 1840 figure among the most speciesrich genera in the family and the genus includes about 80 species. Its geographical distribution comprises most of cis-Andean South America, from Trinidad to Argentina, including the Orinoco, Amazon, and Paraguay-Paraná basins and most coastal rivers between Guianas and the La Plata River (Kullander, 1982; Ploeg, 1991; Lucena and Kullander, 1992; Kullander, 1998, 2003). Based on characteristics such as body shape, the number of scale series below lateral lines, and presence or absence of a humeral blotch, the Crenicichla species are included into nine groups (lugubris, acutirostris, lacustris, missioneira, reticulata, saxatilis, scotti, wallacii, and macrophtalma) or into two more inclusive groups: large-scaled and small-scaled spe-

Send correspondence to Eliana Feldberg. Instituto Nacional de Pesquisas da Amazônia, Coordenação de Pesquisas em Biologia Aquática, Caixa Postal 478, 69011-970 Manaus, AM, Brazil. E-mail: feldberg@inpa.gov.br. cies (Ploeg, 1991; Lucena and Kullander, 1992; Kullander and Lucena, 2006).

The family Cichlidae is considered a group with a conservative chromosome macrostructure, where $60 \%$ of the analysed species have a diploid number of 48 chromosomes (Feldberg et al., 2003). This characteristic has been proposed by some authors as a conserved character for this family, suggesting that the ancestral karyotype consisted of 48 acrocentric chromosomes (Thompson, 1979; Kornfield et al., 1979; Martins et al., 1995; Feldberg et al., 2003).

The aim of this paper is to update the karyotypic information on Crenicichla species and to present additional cytogenetic data for six species, and to evaluate the usefulness of cytotaxonomic information for the understanding of the evolution of pike cichlids.

Karyotype analyses were performed on Crenicichla cincta (eight males, seven females), C. inpa (five males, seven females), $C$. reticulata (two males, one female), $C$. lugubris (five males, three females), $C$. cf. johanna (one male, one female), and C. britskii (one male). The five former species were collected in the area near the confluence of the Negro and Solimões Rivers and the surrounding area (between $59^{\circ}-60^{\circ} \mathrm{W}$ and $2^{\circ}-3^{\circ} \mathrm{S}$ ), and C. britskii was col- 
lected in the Paraná River near the Jupiá Hydroelectric Dam in the Paraná-Paraguai basin $\left(51^{\circ} 35^{\prime} 35^{\prime \prime} \mathrm{W}\right.$ and $\left.20^{\circ} 45^{\prime} 55^{\prime \prime} \mathrm{S}\right)$. The specimens were deposited in the collection of Laboratório de Genética de Peixes (INPA/CPBA).

Chromosome preparations were obtained from a kidney cell suspension using the standard air-drying technique of Bertollo et al. (1978). Fish were anesthetized in chilled water before being sacrificed. Mitotic induction with biological yeast (Oliveira et al., 1988) was performed in order to obtain a higher number of dividing cells. Nucleolar organizer regions (NORs) were identified by silver nitrate staining according to Howell and Black (1980), and C-banding to locate constitutive heterochromatin was performed using barium hydroxide according to Sumner (1972). When pos- sible, slides were stained sequentially with Giemsa, Cbanding, and silver nitrate solution (Ag-NOR) according to Centofante et al. (2002). Chromosomes were measured and arranged in decreasing order of size into two groups: metacentric-submetacentric (M-SM) and subtelocentric-acrocentric (ST-A) according to Levan et al. (1964) and Thompson (1979). The fundamental number (FN) or chromosome arm number was determined by counting M-SM chromosomes with two arms and ST-A with only one.

Table 1 summarizes the chromosome characteristics of the Crenicichla species that were analyzed in the present study and those available in the literature. These data are hierarchically organized according to the species group division proposed by Ploeg (1991) and Lucena and Kullander

Table 1 - Chromosome characteristics in the genus Crenicichla $(2 \mathrm{n}=$ diploid number; $\mathrm{KF}=$ karyotypic formula; $\mathrm{FN}=$ fundamental number; $\mathrm{NOR}=\mathrm{Nu}-$ cleolar organizer region, $\mathrm{p}=$ short arm, $\mathrm{q}=$ long arm, $\mathrm{t}=$ terminal, $\mathrm{i}=$ interstitial; $*=$ updated species names as shown in the Fish Database http://www.fishbase.org/search.cfm.

\begin{tabular}{|c|c|c|c|c|c|c|c|}
\hline Group & Species & Locality & $2 \mathrm{n}$ & $\mathrm{KF}$ & FN & NOR(Pair) & Reference \\
\hline \multirow[t]{9}{*}{ saxatilis } & Crenicichla "sexatilis" & Uruguai & 48 & $4 \mathrm{~m}, \mathrm{sm}+44 \mathrm{st}, \mathrm{a}$ & 52 & - & Oyhenart-Perera et al., 1975 \\
\hline & Crenicichla lepidota & & 48 & - & & - & Schell, 1973 \\
\hline & Crenicichla lepidota & Miranda, MS, Brazil & 48 & $6 \mathrm{~m}, \mathrm{sm}+42 \mathrm{st}, \mathrm{a}$ & 54 & $1^{\circ}, \mathrm{q}, \mathrm{i}$ & Feldberg and Bertollo, 1985a, b \\
\hline & Crenicichla lepidota & Commercial source & 48 & $6 \mathrm{~m}, \mathrm{sm}+42 \mathrm{st}, \mathrm{t}$ & 54 & - & Thompson, 1979 \\
\hline & Crenicichla lepidota & $\begin{array}{l}\text { Paraná River, PR, } \\
\text { Brazil }\end{array}$ & 48 & $6 \mathrm{~m}, \mathrm{sm}+42 \mathrm{st}, \mathrm{a}$ & 54 & $\begin{array}{c}1^{\circ}, \mathrm{p}, \mathrm{t} 5^{\circ} \\
\mathrm{q}, \mathrm{t}\end{array}$ & Martins et al., 1995 \\
\hline & Crenicichla lepidota & Misiones, Argentina & 48 & $6 \mathrm{~m}, \mathrm{sm}+42 \mathrm{st}, \mathrm{a}$ & 54 & $1^{\circ},-, \mathrm{i}$ & Fenocchio et al., 2003 \\
\hline & Crenicichla lucius & Commercial source & 48 & - & & - & Thompson, 1979 \\
\hline & Crenicichla inpa & $\begin{array}{l}\text { Br 174, km 14, AM, } \\
\text { Brazil }\end{array}$ & 48 & $6 \mathrm{~m}, \mathrm{sm}+42 \mathrm{st}, \mathrm{a}$ & 54 & $1^{\circ}, \mathrm{q}, \mathrm{i}$ & Present paper \\
\hline & Crenicichla britskii & Jupiá River, PR, Brazil & 48 & $8 \mathrm{~m}, \mathrm{sm}+40 \mathrm{st}, \mathrm{a}$ & 56 & $4^{\circ}, \mathrm{q}, \mathrm{t}$ & Present paper \\
\hline \multirow[t]{6}{*}{ lacustris } & Crenicichla iguassuensis & $\begin{array}{l}\text { Iguaçu River, PR, } \\
\text { Brazil }\end{array}$ & 48 & $8 \mathrm{~m}, \mathrm{sm}+40 \mathrm{st}, \mathrm{a}$ & 56 & $1^{\circ},-, \mathrm{i}$ & $\begin{array}{l}\text { Mizoguchi and Martins-San- } \\
\text { tos, } 2000\end{array}$ \\
\hline & Crenicichla iguassuensis & $\begin{array}{l}\text { Iguaçu River, PR, } \\
\text { Brazil }\end{array}$ & 48 & $6 \mathrm{~m}, \mathrm{sm}+42 \mathrm{st}, \mathrm{a}$ & 54 & $1^{\circ}, \mathrm{p}, \mathrm{i}$ & $\begin{array}{l}\text { Lorscheider and } \\
\text { Margarido, } 2004\end{array}$ \\
\hline & Crenicichla lacustris & Registro, SP, Brazil & 48 & $6 \mathrm{~m}, \mathrm{sm}+42 \mathrm{st}, \mathrm{a}$ & 54 & $1^{\circ}, \mathrm{p}, \mathrm{i}$ & Feldberg and Bertollo, 1985a, b \\
\hline & Crenicichla niederleinii & $\begin{array}{l}\text { Paraná River, PR, } \\
\text { Brazil }\end{array}$ & 48 & $14 \mathrm{~m}, \mathrm{sm}+34 \mathrm{st}, \mathrm{a}$ & 62 & $1^{\circ}, \mathrm{p}, \mathrm{i}$ & Martins et al., 1995 \\
\hline & Crenicichla niederleinii & $\begin{array}{l}\text { Tibagí River, PR, } \\
\text { Brazil }\end{array}$ & 48 & $10 \mathrm{~m}, \mathrm{sm}+40 \mathrm{st}, \mathrm{a}$ & 58 & $2 \mathrm{cr}$ & Loureiro et al., 2000 \\
\hline & Crenicichla niederleinii & Misiones, Argentina & 48 & $6 \mathrm{~m}, \mathrm{sm}+42 \mathrm{st}, \mathrm{a}$ & 54 & $1^{\circ}, \mathrm{p}, \mathrm{i}$ & Fenocchio et al., 2003 \\
\hline wallacii & Crenicichla notophthalmus & Commercial source & 48 & $6 \mathrm{~m}, \mathrm{sm}+42 \mathrm{st}, \mathrm{a}$ & 54 & - & Thompson, 1979 \\
\hline \multirow[t]{4}{*}{ reticulata } & Crenicichla reticulata & $\begin{array}{l}\text { Uatumã River, AM, } \\
\text { Brazil }\end{array}$ & 48 & $6 \mathrm{~m}, \mathrm{sm}+42 \mathrm{st}, \mathrm{a}$ & 54 & $1^{\circ}, \mathrm{p}, \mathrm{i}$ & Feldberg et al., 2004 \\
\hline & Crenicichla reticulata & Careiro, AM, Brazil & 48 & $6 \mathrm{~m}, \mathrm{sm}+42 \mathrm{st}, \mathrm{a}$ & 54 & $1^{\circ}, \mathrm{p}, \mathrm{i}$ & Present paper \\
\hline & Crenicichla semifasciata & Misiones, Argentina & 48 & $6 \mathrm{~m}, \mathrm{sm}+42 \mathrm{st}, \mathrm{a}$ & 54 & $1^{\circ},-, \mathrm{i}$ & Fenocchio et al., 2003 \\
\hline & Crenicichla semifasciata* & Miranda, MS, Brazil & 48 & $6 \mathrm{~m}, \mathrm{sm}+42 \mathrm{st}, \mathrm{a}$ & 54 & $1^{\circ}, \mathrm{p}, \mathrm{i}$ & Feldberg and Bertollo, 1985a, b \\
\hline \multirow[t]{5}{*}{ lugubris } & Crenicichla strigata & Commercial source & 48 & $6 \mathrm{~m}, \mathrm{sm}+42 \mathrm{st}, \mathrm{a}$ & 54 & - & Thompson, 1979 \\
\hline & Crenicichla vittata & Miranda, MS, Brazil & 48 & $6 \mathrm{~m}, \mathrm{sm}+42 \mathrm{st}, \mathrm{a}$ & 54 & $1^{\circ}, \mathrm{p}, \mathrm{i}$ & Feldberg and Bertollo, 1985a, b \\
\hline & Crenicichla cincta & Catalão, AM, Brazil & 48 & $8 \mathrm{~m}, \mathrm{sm}+40 \mathrm{st}, \mathrm{a}$ & 56 & $1^{\circ}, \mathrm{p}, \mathrm{t}$ & Present paper \\
\hline & Crenicichla lugubris & Catalão, AM, Brazil & 48 & $8 \mathrm{~m}, \mathrm{sm}+40 \mathrm{st}, \mathrm{a}$ & 56 & $3^{\circ}, \mathrm{q}, \mathrm{t}$ & Present paper \\
\hline & Crenicichla cf. johanna & Catalão, AM, Brazil & 48 & $8 \mathrm{~m}, \mathrm{sm}+40 \mathrm{st}, \mathrm{a}$ & 56 & $24^{\circ}, \mathrm{p}, \mathrm{t}$ & Present paper \\
\hline Unidentified & Crenicichla sp. & $\begin{array}{l}\text { São Benedito River, } \\
\text { Itajaí, SC, Brazil }\end{array}$ & 48 & $8 \mathrm{~m}, \mathrm{sm}+40 \mathrm{st}, \mathrm{a}$ & 56 & $2 \mathrm{cr}$ & Loureiro et al., 2000 \\
\hline
\end{tabular}


(1992). All species analyzed in the present study exhibited $2 \mathrm{n}=48$ chromosomes. Although the overall karyotypes are uniform (Figure 1A-F), they could be separated into two groups, based on their chromosomal formulae: C. cincta, $C$. lugubris, C. cf. johanna, and C. britskii exhibit $8 \mathrm{M}-\mathrm{SM}+40 \mathrm{ST}-\mathrm{A}$ and $\mathrm{FN}=56$, and $C$. inpa and $C$. reticulata exhibit $6 \mathrm{M}-\mathrm{SM}+42 \mathrm{ST}-\mathrm{A}$ and $\mathrm{FN}=54$. No sex heteromorphism was detected in species where it was possible to analyze males and females.

A single pair of NORs was observed in all six species; however, these cistrons were located on different chromosome pairs and/or different locations. In C. cincta the AgNORs were located on the terminal region of the short arms of the first pair (M-SM); in C. inpa they were located on the interstitial region of the long arms of the first pair (M-SM); in C. reticulata the Ag-NORs were located on the interstitial region of the short arms of the first pair (M-SM); in $C$. lugubris the Ag-NORs were located on the terminal region of the long arms of the third pair (M-SM); in C. cf. johanna the Ag-NORs were located on the terminal region of the short arms of the $24^{\text {th }}$ pair (ST-A); and in C. britskii the Ag-NORs were located on the terminal region of the long arms of the fourth pair (M-SM). Heteromorphism in the size of the NORs was detected in all species, more markedly in C. britskii and C. cf. johanna (Figure 1A-F).

All the six analyzed species were characterized by several C-band positive heterochromatin blocks in the pericentromeric region of all chromosomes, although some of theses blocks were more conspicuous than others. In $C$. cincta, C. inpa and C. reticulata, the Ag-NORs were not coincident with heterochromatic blocks, although these ribosomal cistrons were closely adjacent to clearly evident C-bands. In contrast, in $C$ lugubris, $C$. cf. Johanna, and $C$. britskii, Ag-NORs were coincident with C-bands. Moreover, some other conspicuous heterochromatic blocks could also be observed in the six species. C. reticulata presented an interstitial heterochromatic block on the long arms of the $10^{\text {th }}$ chromosome pair of its karyotype complement. C. lugubris showed an interstitial C-band on the long arms of the second chromosome pair, and $C$. cf. johanna has a terminal heterochromatic block on the long arms of the $19^{\text {th }}$ chromosome pair. In $C$ britskii, it was possible to detect a heterochromatic block that occupies the whole short arms of the first chromosome pair (Figure 1 G-L). These unique heterochromatic blocks are chromosome markers that could also be useful in future comparisons among several Crenicichla species.

The relationships among Neotropical cichlids have been the object of evolutionary studies using morphological (Kullander, 1998), molecular (Farias et al., 2000), and karyological data (Feldberg et al., 2003). All these data agree that Neotropical cichlids form a monophyletic group.

According to Kullander (1998), Neotropical cichlids are organized in five major lineages, where the subfamily Cichlinae occupies a basal position and encompass only two genera: Cichla and Crenicichla. In a recent review, Feldberg et al. (2003) showed that Crenicichla and Cichla appear to fall into different karyoevolution directions. Cichla species exhibit only acrocentric chromosomes and seem to be the most primitive (Thompson, 1979; AlvesBrinn et al., 2004), while Crenicichla exhibits chromosomal variability in characteristics like karyotypic formula and fundamental chromosome number (Thompson, 1979; Feldberg and Bertollo, 1985a,b; Martins et al., 1995; Loureiro et al., 2000; present paper). According to Thompson (1979), the presence of a greater number of meta-submetacentric chromosomes characterizes a derived state, since the karyotype considered ancestral for this group has only acrocentric chromosomes.

Whereas Farias et al. (2000) proposed that Crenicichla might be related with Apistogramma forming the subfamily Geophaginae, Feldberg et al. (2003) showed that Crenicichla and Apistogramma fall into different karyoevolution directions with Apistogramma presenting 46 chromosomes. However, a closer look on the chromosomal data presented by the authors reveal that the gross karyotype macrostructure of Crenicichla and the remaining geophagines is quite similar.

In fact, Crenicichla species exhibit a diploid number of 48 chromosomes, except for Crenicichla sp. from the Paraná-Paraguay basin which supposedly possess $2 n=46$ chromosomes (nome dos autores, unpublished data). Often, chromosomal variability can be attributed to problems in analysis, as well as to the interpretation of chromosome measurements. Special care must be taken when these comparisons are made among cichlids, since there are cases where cytogenetic differences indicated the existence of different species (Feldberg et al., 2003; Alves-Brinn et al., 2004).

Data regarding the prevalence of chromosomal rearrangements in Neotropical cichlids have been obtained mainly through conventional cytogenetic studies (Feldberg et al., 2003). Apparently, non-Robertsonian rearrangements, such as paracentric/pericentric inversions and translocation, might be postulated as the source of differentiation among Crenicichla species, taking into account the NORs carriers as a hallmark. Thus, the phenetic NOR character seems to be a good tool for differentiating Crenicichla species (Figure 1, Table 1). Of the 17 nominal Crenicichla species that have already been studied (Table 1), 13 had their NOR pattern determined. All 13 species exhibit a single NOR pattern, with the exception of a population of $C$. lepidota from the Paraná River. This population exhibits four NOR-bearing chromosome markers, characterizing a multiple NOR system (Martins et al., 1995).

According to Feldberg et al. (2003), the general trend in the family Cichlidae is to exhibit a single NOR system, with only one pair of NORs located on the largest chromosome of the complement. This chromosomal character seems to be plesiomorphic for cichlids. This is particularly 


\begin{tabular}{|c|c|c|c|}
\hline $\begin{array}{l}\mathrm{A} \\
\mathrm{M}-\mathrm{SM}\end{array}$ & 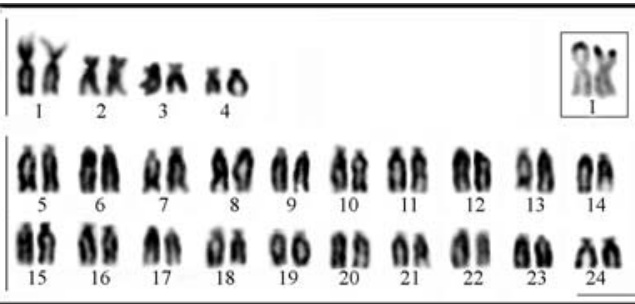 & \begin{tabular}{|l|}
$\mathrm{G}$ \\
$\mathrm{M}-\mathrm{SM}$
\end{tabular} & 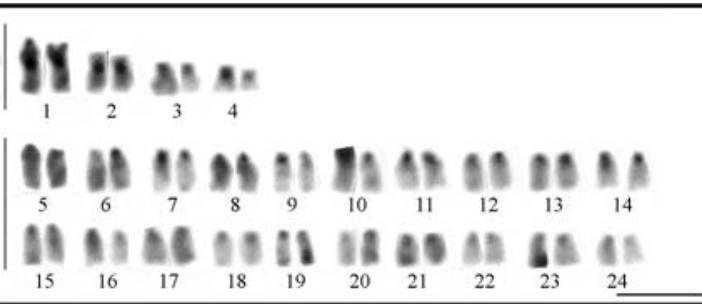 \\
\hline $\begin{array}{l}\text { B } \\
\text { M-SM }\end{array}$ & 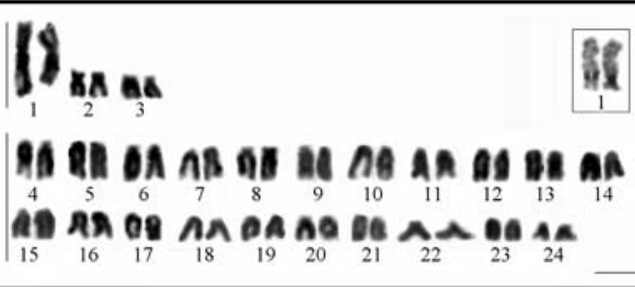 & \begin{tabular}{|l|}
$\mathrm{H}$ \\
$\mathrm{M}-\mathrm{SM}$
\end{tabular} & 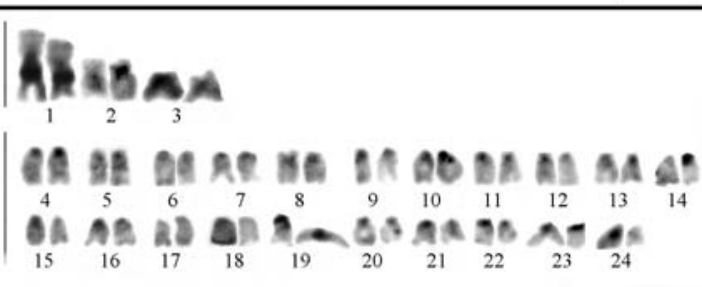 \\
\hline $\begin{array}{l}\text { C } \\
\text { M-SM }\end{array}$ & 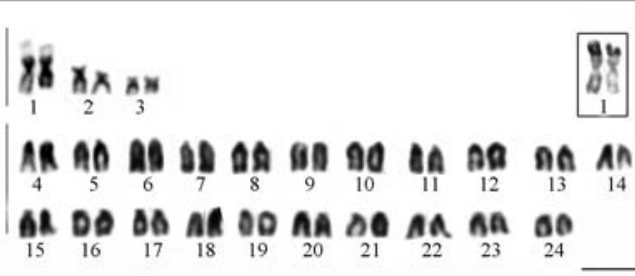 & $\left|\begin{array}{c}\text { I } \\
\text { M-SM }\end{array}\right|$ & 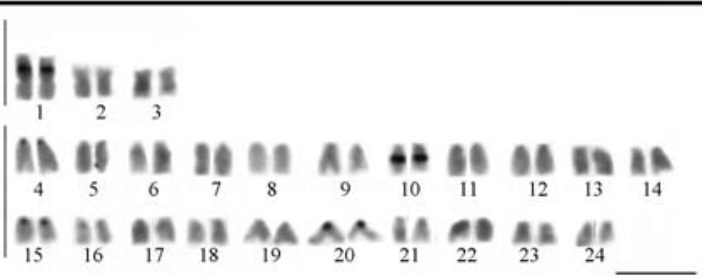 \\
\hline $\begin{array}{l}\text { D } \\
\text { M-SM }\end{array}$ & 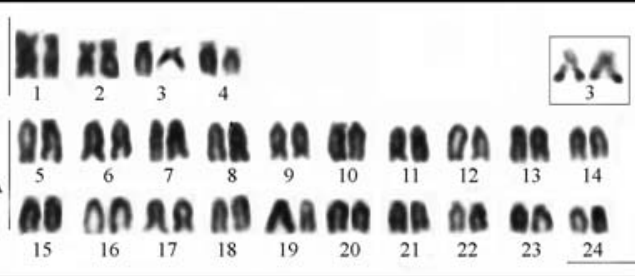 & \begin{tabular}{|c|} 
J \\
M-SM
\end{tabular} & 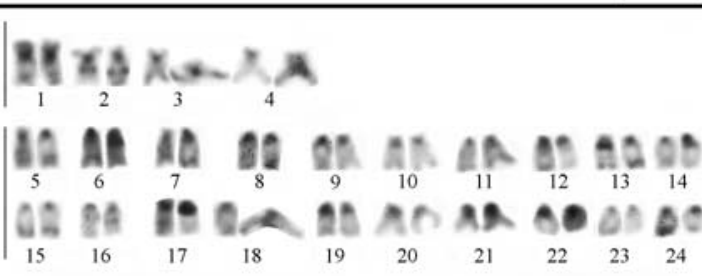 \\
\hline $\begin{array}{l}\text { E } \\
\text { M-SM }\end{array}$ & $\begin{array}{l}\text { Do } \\
24\end{array}$ & \begin{tabular}{l|}
$\mathrm{K}$ \\
$\mathrm{M}-\mathrm{SM}$
\end{tabular} & 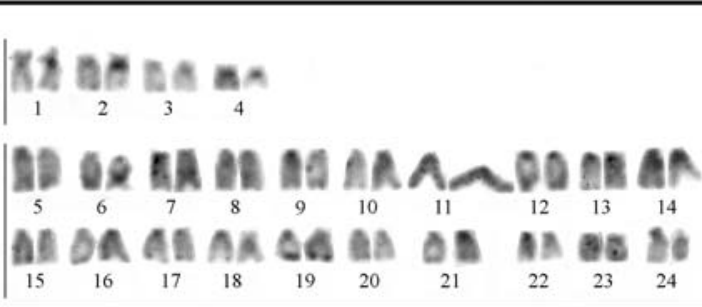 \\
\hline $\begin{array}{l}\text { F } \\
\text { M-SM }\end{array}$ & 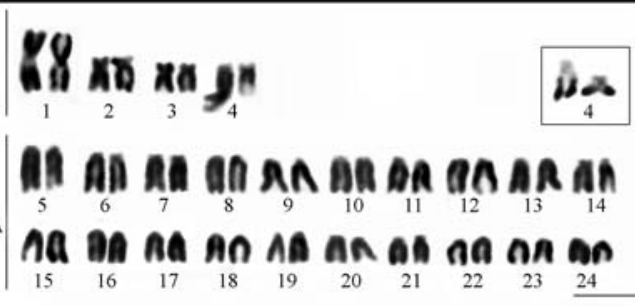 & $\left|\begin{array}{l}\mathrm{L} \\
\mathrm{M}-\mathrm{SM}\end{array}\right|$ & 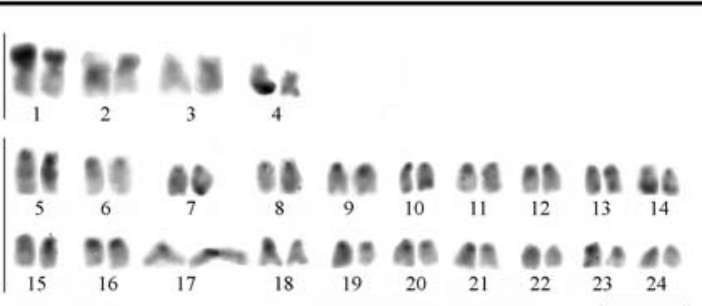 \\
\hline
\end{tabular}

Figure 1 - Conventional Giemsa-stained and C-banding karyotypes of: (A and G) C. cincta; (B and H) C. inpa; (C and I) C. reticulata; (D and J) C. lugubris; (E and $\mathrm{K})$ C. cf. johanna; and (F and L) C. britskii. In evidence, Ag-NORs pairs. Bar represents $10 \mu \mathrm{m}$.

true for the majority of the Crenicichla species. Every time that a large M-SM chromosome pair is observed, it usually bears Ag-NORs (except for Crenicichla britskii). When such a large M-SM chromosome pair is not so evident, then the Ag-NORs position is not on the first chromosome pair. In this way, $C$. reticulata, $C$. inpa, and $C$. cincta might be considered more primitive than C. cf. joahna, C. lugubris, and C. britskii, although the last species also presents a large M-SM chromosome pair in the complement.
Feldberg et al. (2003) also reported that constitutive heterochromatin, in the few Neotropical cichlids analyzed so far, is present in the pericentromeric region of all chromosomes or in most of them. However, interspecific differences are clearly observed in Crenicichla, where interstitial and/or telomeric blocks, as well as regions at or near the NORs, reflect part of the chromosomal differentiation of the species.

The heterochromatin patterns of the species analyzed here are very similar; however, each species exhibits at 
least one species-specific block (Figure 1G-L). In addition, sequential Ag-NOR staining/C-banding in the same metaphase led us to observe the correspondence of C-bands and NORs in Clugubris, C. cf Johanna, and C. britskii, indicating the presence of heterochromatin associated with ribosomal cistrons. Yet, in C. cincta, C. inpa, and C. reticulata the $\mathrm{Ag}$-NORs were $\mathrm{C}$-band negative, but adjacent to a heterochromatic block.

Several studies in fish shave shown that the association of heterochromatin and NORs is an important element in chromosome differentiation. For example, Galetti et al. (1991) postulated for anostomids that heterochromatin associated with NORs may have favored breaks and consequent rearrangements during the chromosomal evolution. Furthermore, Ruiz et al. (1981) and Clark and Wall (1996) claimed that constitutive heterochromatin is often associated with ribosomal cistrons in the NORs of eukaryotic chromosomes. Thus, we are assuming for Crenicichla species that the association of heterochromatin and NORs would have played an important role in their chromosomal differentiation.

Our comparisons of cytogenetic patterns of the genera Cichla and Crenicichla make it clear that Crenicichla presents a more derived condition. It is interesting to note that Crenicichla possesses a much wider natural distribution than Cichla. Species of the C. lacustris group, which are restricted to the southern portion of the genus distribution, exhibit less-conserved characteristics than other members of this taxon. This may indicate that the dispersion and speciation of the genus Crenicichla involved non-Robertsonian rearrangements, principally inversions, and that these have occurred from North to South on the South American continent.

\section{Acknowledgments}

The authors thank AM Silva and ML Terencio for the helpful analysis of the final version of de manuscript. This work was supported by the Instituto Nacional de Pesquisas da Amazônia (INPA), through the Research Institutional Projects (PPI 2-3450), Conselho Nacional de Desenvolvimento Científico e Tecnológico (CNPq)/Programa de apoio a Núcleos de Excelência em Ciência e Tecnologia (PRONEX), and Programa Norte de Pós-graduação (PNOPG), Fundação de Amparo à Pesquisa do Estado do Amazonas (FAPEAM)/Programa Integrado de Pesquisa e Inovação Tecnológica (PIPT), and IBAMA - Licence $\mathrm{N}^{\circ}$ 011/2005. DCB and MCG received scholarships from CNPq.

\section{References}

Alves-Brinn MN, Porto JIR and Feldberg E (2004) Karyological evidence for interspecific hybridization between Cichla monoculus and C. temensis (Perciformes, Cichlidae) in the Amazon. Hereditas 141:252-257.
Bertollo LAC, Takahashi CS and Moreira Filho O (1978) Cytotaxonomic considerations on Hoplias lacerdae (Pisces, Erythrinidae). Braz J Genet 7:103-120.

Centofante L, Porto JIR and Feldberg E (2002) Chromosomal polymorphism in Serrasalmus spilopleura Kner, 1858 (Characidae, Serrasalminae) from Central Amazon basin. Caryologia 55:37-45.

Clark MS and Wall WJ (1996). Chromosomes: The Complex Code. Chapman \& Hall, London, 345 pp.

Farias IP, Ortí G and Meyer A (2000) Total evidence: Molecules, morphology and the Phylogenetics of Cichlid fishes. J Exp Zool 288:76-92.

Felberg E and Bertollo LAC (1985a) Karyotype of the 10 species of Neotropical cihlids (Pisces, Perciformes). Caryologia 38:257-268.

Feldberg E and Bertollo LAC (1985b) Nucleolar organizing regions in some species of neotropical Cichlid fishes (Pisces, Perciformes). Caryologia 38:319-324.

Feldberg E, Porto JIR and Bertollo LAC (2003) Chromosomal changes and adaptation of cichlid fishes during evolution. In: Val AL and Kapoor BG (eds) Fish Adaptation. IBH \& Oxford, New Dehli \& New York, pp 287-310.

Feldberg E, Porto JIR, Alves-Brinn MN, Mendonça MNC and Benzaquem DC (2004) B chromosomes in Amazonian cichlid species. Cytogenet Genome Res 106:195-198.

Fenocchio AS, Pastori MC, Roncati H, Moreira Filho O and Bertollo LAC (2003) A cytogenetic survey of the fish fauna from Argentina. Caryologia 56:197-204.

Galetti Jr PM, Mestriner CA, Venere PC and Foresti F (1991) Heterocromatin and karyotype reorganization in fish of the family Anostomidae (Characiformes). Cytogenet Cell Genet 56:116-121.

Howell WM and Black DA (1980) Controlled silver-staining of nucleolus organizer regions with a protective colloidal developer: A 1-step method. Experientia 63:1014-1015.

Kornfield V, Richer C and Warman J (1979) Biochemical and cytological differentiation among Cichlid fish of the Sea of Galilee. Evolution 33:1-14.

Kullander SO (1982) Cichlid Fishes from the La Plata basin. Part III. The Crenicichla lepidota species group (Teleostei, Cichlidae). Rev Suisse Zool 89:33-48.

Kullander SO (1998) A phylogeny and classification of the South American Cichlidae (Teleostei, Perciformes). In: Malabarba LR, Reis RE, Vari RP, Lucena ZM and Lucena CAS (eds) Phylogeny and Classification of Neotropical Fishes. EDIPUCRS, Porto Alegre, pp 461-498.

Kullander SO (2003) Family Cichidae. In. Reis RE, Kullander SO and Ferraris Jr CJ (eds) Check List of the Freshwater Fishes of South and Central America. EDIPUCRS, Porto Alegre, pp 605-654.

Kullander SO and Lucena CAS (2006) A review of the species of Crenicichla (Teleostei, Cichlidae) from the Atlantic coastal rivers of southeastern Brazil from Bahia to Rio Grande do Sul States, with descriptions of three new species. Neotrop Ichthyol 4:127-146.

Levan A, Fredga K and Sabdberg AA (1964) Nomenclature for centromeric position on chomosomes. Hereditas 52:201220.

Lorscheider CA and Margarido VP (2004) Estudos citogenéticos comparativos em Crenicichla niederleinii e Crenicichla 
iguassuensis (Perciformes, Cichlidae). Anais do X Simpósio de Citogenética e Genética de Peixes, Natal, pp 111.

Loureiro MA, Giuliano-Caetano L and Dias AL (2000) Cytogenetic characterization of two species of the genus Crenicichla (Pisces, Cichlidae). Cytologia 65:57-63.

Lucena CAS and Kullander SO (1992) The species of the Uruguai River drainage in Brazil. Ichthyol Explor Freshwaters 3:97160.

Martins IC, Portella-Castro ALB and Julio Jr HF (1995) Chromosome analysis of 5 species of the Cichlidae family (Pisces, Perciformes) from the Paraná River. Cytologia 60:223-231.

Mizoguchi SHN and Martins-Santos IC (2000) Caracterização cromossômica de três espécies da família Cichlidae (Pisces, Perciformes) do rio Iguaçu. Anais do VIII Simpósio de Citogenética e Genética de peixes, Manaus, pp 32.

Oliveira C, Almeida-Toledo LF, Foresti F and Toledo-Filho SA (1988) Supernumerary chromosomes, Robertsonian rearrangement and multiple NORs in Corydoras aeneus (Pisces, Siluriformes, Callichyidae). Caryologia 41:227-236.

Oyhenart-Perera MF, Luengo JA and Brum-Zorrilla N (1975) Estudio citogenetico de Cichlasoma facetum (Jenyns) y
Crenicichla sexatilis (Linn.) (Teleostei, Cichlidae). Rev Biol del Uruguay 3:29-36.

Ploeg A (1991) Revision of the South American cichlid genus Crenicichla Heckel, 1840, with descriptions of fifteen new species groups, phylogeny and biogeography (Pisces, Perciformes, Cichlidae). PhD Thesis, Universiteit van Amsterdam, Netherland.

Ruiz IRG, Soma M and Beçak W (1981) Nucleolar organizer regions and constitutive heterochromatin in polyploid species of the genus Odontophrynus (Amphybia, Anura). Cytogenet Cell Genet 29:84-98.

Schell JJ (1973) Chromosomen-evolution bei Fischen. In: Fish Chromosomes and their Evolution. Internal report of Danmarks Akvarium, Charlottenlund, pp 1-22.

Sumner AT (1972) A simple technique for demonstration centromeric heterochromatin. Exp Cell Res 74:304-306.

Thompson KW (1979) Cytotaxonomy of 41 species of Neotropical Cichlidae. Copeia 1979:679-691.

\section{Internet Resources}

Fish Database, http://www.fishbase.org/search.cfm (access on july 19th, 2006).

Associate Editor: Fausto Foresti

License information: This is an open-access article distributed under the terms of the Creative Commons Attribution License, which permits unrestricted use, distribution, and reproduction in any medium, provided the original work is properly cited. 